\title{
Rubén Darío y la condición humana de Pablo Kraudy Medina²
}

\section{Año del centenario de su muerte (1916-2016)}

Recibido: 25.08.2016 / Aprobado: 28.08.2016

Por Jorge Eduardo Arellano

En 2005, con motivo de los cien años del poemario cimero de Rubén Darío, Cantos de vida y esperanza. Los cisnes y otros poemas (Madrid, Tipografía de la Revista de Bibliotecas, Archivos y Museos, 1905. 175 p.) Pablo Kraudy y yo acometimos la tarea de realizar una edición crítica de esa obra valorada en Francia -durante los años cincuenta- como una de las forjadoras del siglo XX. La entonces directora general del Instituto Nicaragüense de Cultura, Magdalena Úbeda de Rodríguez, la presentó, en virtud del apoyo económico que obtuvo de la Real Biblioteca de Suecia para imprimirla. El dariano nicaragüense Eduardo Zepeda-Henríquez describió tipográficamente la editio princeps, mientras yo me encargué del prólogo, de las notas contextuales relativas a cada uno de los sesenta y dos poemas (datos de composición y publicación, aspectos formales, fuentes, juicios); de la amplia bibliografía y de los apéndices (uno sobre los veintisiete manuscritos consultados y el otro sobre la métrica y los modelos estróficos que utilizó Darío en su opus rotundum).

Pero el trabajo medular le correspondió a Pablo Kraudy Medina (Matagalpa, 1964). Es decir, el criterio de edición (modernización de ortografía literal y acentual, entre otras iniciativas) y la fijación del texto, sustentado en la edición príncipe y en variantes de manuscritos y publicaciones en revistas, más las notas al pie que aclaran las múltiples referencias culturalistas, hechos y personajes mitológicos e históricos. Sin ellas, Darío correo el peligro de no ser entendido ni disfrutado como lo merece. Porque a nuestro Rubén - sostenía Luis Rosales - hay que considerarlo un clásico moderno. Y como tal debe ser estudiado y difundido. Sin embargo, esto no ha sido posible, pues abundan las publicaciones sin rigor filológico y son escasas las que lo contienen.

Por eso cabe reconocer la concienzuda labor de Kraudy Medina, uno de nuestros intelectuales más destacados. Dariano desde los años 80, cuando colaboró sustancialmente con Fidel Coloma (19231995) en sus ediciones, ha iniciado en Nicaragua la disciplina de la historia social de las ideas, habiendo obtenido con su investigación sobre el pensamiento de la conquista el Premio Nacional de Historia 2001, convocado por el Banco Central de Nicaragua. Es autor de no pocos estudios sobre Darío, entre ellos Modernidad, democracia y elecciones en Rubén Darío, Premio Nacional Idem 2001, anotó varios de los Escritos políticos (2010) de RD y la primera edición en Nicaragua de la novela El Oro de Mallorca (2013). También a él se le debe la preparación, en cinco tomos, de la Obra de Alejandro Serrano Caldera.

No era de extrañar, en consecuencia, que Kraudy Medina reuniera ocho ensayos, o prospecciones críticas, sobre el nicaragüense máximo, en este libro serio y novedoso. La función cívicopolítico del escritor, la pasión por el arte, la esperanza, los desheredaros de la suerte, las elecciones, la guerra y la paz, entre otros, constituyen los aspectos abordados por él con erudición y lucidez.

Yo me siento muy satisfecho al editar Rubén Darío y la condición humana de mi amigo y colaborador Pablo Kraudy Medina, uno de los más valiosos dariístas actuales del planeta.

\footnotetext{
1 Managua, JEA-EDITOR, Julio 2016. 222p.

2 Escritor, profesor de Filosofía en la UNAN-Managua, editor crítico, premio nacional Rubén Darío y de Historia.

3 Historiador nicaragüense.
} 